\title{
From Ekman: The Forest of Hours
}

STRAnDS OF TIME run through the forest. The high Ofields of scree are solidified waves of stone, long swells of unmoving time. Tall trees, once whispering in the wind, have sunk into the peatbogs, where the marshy pools are fermenting a brew of time. Here and there, flowering woodland penetrates the darkness of the firs and the sea of stones, forming wedges of broad-leaved trees, fragrant night-flowering plants and humming frail-winged insects. There, the noble trees are singing. The leaves of linden and hazel are dancing in a gentler wind and their roots send fibrils into a richer soil than the meagre ground under the firs. It is forgotten woodland, flowering in borrowed time...

People have always tried to slash and burn their way into the forest. And when it proved resilient, when even the goats failed to tear the bark off the trees, they tried to control it by naming. They found everything malevolent in the forest: stinkweed and wormwood, devil's nettle, dead man's bells and poison parsley. They named the plants which neither stank nor stung nor killed according to who fed on them: hawkweed, bear's foot, cowgrass, swine's snout and chickweed, hare's thistle, bee's nest and cuckoo's meat. For some, playfulness and for others plain practicality.

The rest became known as grass to most people, but there were those who named also the useless and the lovely ones: sweetfern and rose bay willow, forget-me-not, sweet cicely, water nymph, angel's eye and herb of grace, such were their names. 
But the forest just grew and flowered. It flowered with senseless frenzy, remote from their names, and some wanderers came all the way, down into the deepest hollows under the stones and the darkness of marshland pools, and onto the steep silent braes of the lochs and they named the alien growths in these places and called them bog onion and brittle bladder fern, ghost orchid and pinesap. But it was not enough. The forest flowered on heedlessly, long after they had been silenced, roots twisting through their gaping mouths. It flowered known and named only by those who hummed and clicked and twittered, by the rustle of wings and rattle of claws and thud of antlers against tree trunks.

(The Forest of Hours by Kerstin Ekman, trnsl. Anna Paterson,

Chatto \& Windus, 1998 pp. 310-11) 